\title{
PENGARUH PEMBERIAN EKSTRAK ETANOL DAUN BUAS-BUAS (Premna cordifolia. LINN) TERHADAP KADAR MDA TIKUS WISTAR JANTAN PASCA PAPARAN ASAP ROKOK
}

\author{
Asri Adyttia ${ }^{* *}$, Eka Kartika Untari ${ }^{2}$, Sri Wahdaningsih ${ }^{3}$ \\ 1.Program Studi Farmasi, Fakultas Kedokteran, Universitas Tanjungpura \\ ${ }^{2}$ Bagian Farmakologi Farmasi, Fakultas Kedokteran, Universitas Tanjungpura \\ ${ }^{3}$ Bagian Biologi Farmasi, Fakultas Kedokteran, Universitas Tanjungpura \\ *)Email:
}

\begin{abstract}
Free radical from cigarrete smoke can cause lipid peroxidation that could lead to tissue damage. Tissue damage can be identified by increased levels of MDA (Malondialdehyde). Leavesof buas-buas (Premna cordifolia. Linn) has an antioxidant activity in invitro study. This study aimed to analyze the effect of P. cordifolia leaves extract on the levels of malondialdehyde (MDA) after exposure to cigarette smoke. The simplicia extracted by maseration using $70 \%$ ethanol. Twenty four wistar strain of Rattus novergicus were divided into six groups, i.e. : normal group without any treatment, positive control group with cigarette smoke exposure and vitamin e treatment, negative control groupwith only cigarette smoke exposure, treatment groupwith cigarette smoke exposure and ethanolic extract from P. cordifolialeaves with doses 200; 400; $600 \mathrm{mg} / \mathrm{kg}$ of body weight/day. All rats were treated for 14 days using 3 cigarette non filetered each day. After 14 days, plasma MDA was measured in this research. Measurement of plasma MDA are using Spectrophotometer UV-Vis in $532.2 \mathrm{~nm}$. MDA level in this study was analyzed by the Kruskal-Wallis and Mann-Whitney test. The result showed that plasma MDA level of groupreceived ethanol extract of $P$. cordifolia leaves doses at $600 \mathrm{mg} / \mathrm{kg}$ of body weight/day significantly $(p<0.05)$ lower than negative control group and not significantly differ $(p<0.05)$ to normal group and positive control group.
\end{abstract}

Keyword: Cigarette smoke, plasma MDA, antioxidant, ethanolic extract from P.cordifolia leaves

\section{PENDAHULUAN Latar Belakang}

Merokok merupakan salah satu gaya hidup utama yang berpengaruh pada kesehatan manusia. Sebagian besar perokok berasal dari negara berkembang dan dari golongan sosial ekonomi rendah. Indonesia merupakan negara ketiga yang memiliki jumlah perokok aktif terbanyak di dunia yaitu 61,4 juta perokok setelah Cina dan India. Perilaku merokok penduduk Indonesia cenderung meningkat dari 34,2 persen pada tahun 2007 menjadi 36,3 persen pada tahun 2013. Merokok dalam jangka waktu yang panjang mempunyai pravelensi terhadap beberapa penyakit seperti atherosclerosis dan chronic obstructive pulmonary disease (COPD) dengan dampak sistemik yang signifikan. ${ }^{1,2,3}$.

Rokok mengandung berbagai bahan kimia antara lain nikotin, karbon monoksida, tar dan eugenol (dalam rokok kretek).Asap rokok mengandung 10 14-16 molekul oksidan seperti superoksida, hidrogen peroksida, hidrkosil dan peroksil dalam satu kali hisapan. Asap rokok mengakibatkan stress oksidatif yang ditandai dengan meningkatnya radikal oksidan dan reaksi inflamasi berupa peningkatan jumlah total leukosit dan neutrofil darah perifer. Radikal bebas dari asap rokok menyebabkan peroksidasi dari asam lemak ganda tak jenuh membran sel yang memperkuat stres oksidatif selama merokok. Penggunaan rokok dalam waktu yang lama dapat menyebabkan ketidakseimbangan oksidanantioksidan sistemik yang ditandai dengan adanya hasil dari peroksidasi lipid yaitu MDA (Malondialdehid). Terdapat hubungan antara lama pemaparan rokok dengan peningkatan kadar MDA ${ }^{1 \text {, }}$ $4,5,6,7$.

Antioksidan merupakan senyawa yang berguna mengatasi kerusakan oksidatif akibat radikal bebas dalam tubuh.Daun buas-buas merupakan salah satu alternatif bahan makanan sumber antioksidan yang belum banyak diteliti kegunaannya.Masyarakat umumnya menggunakan daun buas-buas (Premna cordifolia) sebagai bumbu masakan dan makanan.Buas-buas memiliki kandungan kimia fenolik dan flavonoid yang berperan dalam aktivitas antioksidan.Ekstrak methanol daun buas-buas memiliki aktivitas antioksidan yang sangat aktif dengan nilai $\mathrm{IC}_{50}$ sebesar $31,91 \pm 0,43 \mu \mathrm{g} / \mathrm{ml}^{8,}, 9,10$. Penelitian tersebut menjadi dasar dilakukannya pengujian aktivitas antioksidan secara in vivo dari ekstrak etanol $70 \%$ daun buas-buas. Pengujian ini dilakukan dengan mengukur kadar MDA tikus wistar 
jantan yang diberi paparan asap rokok dan ekstrak etanol daun buas-buas.

\section{METODOLOGI PENELITIAN}

\section{A. Alat}

Alat yang digunakan pada penelitian ini adalah blender simplisia (IlinQi FZ-10®), bejana maserasi, cawan krusibel, waterbath (Memmert WNB 14®), timbangan analitik (BEL M254AI $\left.{ }^{2}\right)$, rotary evaporator (Heldolph $囚)$, spektrofotometer UV-Vis (Shimadzu MR 2500®), oven (Memmert UP400®), desikator, timbangan analitik (Precisa $\left.{ }^{\circledR}\right)$, alat-alat gelas (Pyrex Iwakiß), Vortex (Barnstead M37610®), mikropipet (Rainin E1019705K®), blood tube, sonde oral, spuit $1 \mathrm{cc}$ dan 3cc, hot plate (Schott Instrument $\left.{ }^{\circledR}\right)$, mortir dan stamper, alat bedah, sentrifuge, shaker,yellow tip dan smoking chamber.

\section{B. Bahan}

Bahan yang digunakan pada penelitian ini adalah daun buas-buas, vitamin E, etanol 70\% (Merck®), serbuk magnesium, larutan $\mathrm{HCL}$ pekat, larutan $\mathrm{HCl}$ $2 \mathrm{~N}$, larutan $\mathrm{FeCl}_{3} 5 \%$, asam asetat glasial, asam asetat anhidrat, larutan $\mathrm{H}_{2} \mathrm{SO}_{4}$ pekat, larutan $\mathrm{H}_{2} \mathrm{SO}_{4}$ 2N, pereaksi Dragendorff, pereaksi Wagner, pereaksi Mayer, aquades, kloroform, amonia, larutan $\mathrm{NaCl} 10 \%$, gelatin 1\%, CMC Carboxy Methyl Cellulose (CMC), aluminium foil, kertas saring, TBA (tiobarbituricacid),TCA (trichloroacid), TMP (tetrametoksipropana).

\section{Hewan Uji}

Hewan yang digunakan dalam penelitian ini adalah tikus putih (Rattus norvegicus) galur wistarjantan. Sampel diperoleh secara acak yang memenuhikriteria inklusi yaitu tikus putih wistar jantan, umur 2- 3 bulan, berat badan 100-200 gram dan tidak cacat secara anatomi, sedangkan kriteria eksklusinya adalahtikus yang sakit secara fisiologis sebelum perlakuan dan terdapat penurunan berat badan yang drastis.

\section{Tahap Penelitian}

\section{Determinasi Tanaman}

Tanaman buas-buas yang digunakan di determinasi di Laboratorium Biologi Fakultas Matematika dan Ilmu Pengetahuan Alam Universitas Tanjungpura dengan menyerahkan sampel berupa tanaman utuh dari daun, batang, bunga dan buah

\section{Pembuatan Ekstrak}

Metode ekstraksi yang digunakan dalam penelitian ini adalah ekstraksi maserasi.Simplisia daun buas-buas sebanyak 300gram direndam dengan pelarut etanol $70 \%$ sebanyak 6 liter, dilakukan pergantian pelarut setiap $1 \times 24$ jam dan pengadukan sesering mungkin.Kemudian ekstrak etanol tersebut dipekatkan menggunakan rotary evaporator dan waterbath hingga diperoleh ekstrak kental.

\section{Penetapan Susut Pengeringan}

Ekstrak yang digunakan yaitu sebanyak 2,2536; 2,1675; 2,1930 gram dan dimasukkan ke dalam kurs porselen yang sudah mencapai bobot konstan. Kemudian dipanaskan di dalam oven..Pemanasan dilakukan pada suhu $105^{\circ} \mathrm{C}$ dan ditimbang setiap 30 menit hingga bobot konstan setelah dua kali penimbangan. Selama proses pemanasan penutup kurs porselen dibuka. Sebelum dilakukan penimbangan ekstrak terlebih dahulu dimasukkan ke dalam desikator yang berisi silika gel selama 15 menit ${ }^{11}$.Selama penyimpanan di dalam desikator kurs porselen ditutup.

\section{Skrining Fitokima Pemeriksaan Alkaloid}

Larutan ekstrak sebanyak 1 mlditambahkan dengan $1 \mathrm{ml}$ asam sulfat $2 \mathrm{~N}$ dan dikocok.Ditambahkan $1 \mathrm{ml}$ kloroform, dikocok hingga terbentuk 2 lapisan.Lapisan atas yang merupakan lapisan asam diambil menggunakan pipet tetes dan ditambahkan $1 \mathrm{ml}$ ammonia. Kemudia larutan dibagi menjdai tiga tabung, tabung $\mathrm{A}$ ditambahkan 3 tetes pereaksi Dragendroff, tabung B ditambahkan 3 tetes perekasi Mayer dan tabung c ditambahkan 3 tetes perekasi Wagner. Hasil positif alkaloid ditandai dengan adanya endapan warna putih pada tabung A dan adanya endapan merah bata pada tabung $\mathrm{B}$ dan $\mathrm{C}^{12}$.

\section{Pemeriksaan Flavonoid}

Larutan ekstrak sebanyak $1 \mathrm{ml}$ ditambah dengan sedikit serbuk magnesium sebanyak 1 gram dan larutan $\mathrm{HCl}$ pekat.Perubahan warna larutan menjadi warna merah menandakan adanya flavonoid ${ }^{13}$.

\section{Pemeriksaan Steroid dan Triterpenoid}

Larutan ekstrak sebanyak $1 \mathrm{ml}$ ditambahkan dengan $1 \mathrm{ml}$ pereaksi Lieberman- Burchard $\left(\mathrm{CH}_{3} \mathrm{COOH}\right.$ glasial dan larutan $\mathrm{H}_{2} \mathrm{SO}_{4}$ pekat).Warna berubah menjadi merah yang menunjukkan adanya senyawa triterpenoid dan warna berubah menjadi biru yang menunjukkan adanya senyawa steroid ${ }^{14}$.

\section{Pemerikasaan Tanin}

Larutan ekstraksebanyak $1 \mathrm{ml}$ ditambahkan $1 \mathrm{ml}$ larutan gelatin $1 \%$ dan diikuti larutan $\mathrm{NaCl} 10 \%$. Hasil positif ditandai dengan terbentuknya endapan putih ${ }^{12}$. 


\section{Pemeriksaan Fenol}

Larutan ekstraksebanyak $1 \mathrm{ml}$ ditambahkan 3 tetes larutan $\mathrm{FeCl}_{3} 5 \%$. Hasil positif yaitu timbul warna biru kehitaman ${ }^{12}$.

\section{Pemeriksaan Saponin}

Larutan ekstraksebanyak $2 \mathrm{ml}$ dimasukkan ke dalam tabung reaksi, lalu ditambahkan dengan air dan dikocok dengan kuat selama 15 menit.Hasil positif ditunjukkan dengan terbentuknya busa dengan tinggi $2 \mathrm{~cm}^{12}$.

\section{Pengujian Aktivitas Antiokisdan Pemaparan Asap Rokok}

Rokok yang digunakan adalah rokok kretek tanpa filter. Semua tikus diberi paparan asap. Proses pemaparan dilakukan dalam smoking chamber. Proses pemaparan dilakukan setiap pagi menggunakan 3 batang rokok. Pemaparan dilakukan selama 14 hari didalam smoking chamber yang terbuat dari plastik ukuran $38,5 \times 28,5 \times 22,5 \mathrm{~cm}$ dilengkapi dengan ventilasi, dua buah air pump dan tempat pembakaran rokok. Satu jam setelah pemaparan asap rokok, tikus diberi ektstrak etanol daun buas-buas sesuai variasi dosis.

\section{Perlakuan Hewan Percobaan}

Seluruh hewan percobaan diadaptasikan selama tujuh hari. Tikus yang diadaptasi akan diberikan makan dan minum secukupnya. Kemudian hewan percobaan dipilih secara acak dibagi menjadi enam kelompok. Kelompok A merupakan kelompok normal tanpa paparan asap rokok dan hanya diberi suspensi CMC 1\% Kelompok B adalah kelompok kontrol postif yang diberikan paparan asap rokok dan vitamin E. Kelompok $\mathrm{C}$ adalah kelompok kontrol negatif yang hanya diberikan paparan asap rokok dan suspensi CMC 1\%. Kelompok D, E dan F adalah kelompok perlakuan yang diberikan paparan asap rokok dan ektrak etanol daun buas-buas dengan dosis 200, 400 dan $600 \mathrm{mg} / \mathrm{kg}$ BB.

\section{Pengambilan Sampel Darah}

Tikus dipuasakan selama 1x24 jam sebelum dilakukan pengambilan darah. Dilakukan dislokasi tulang leher dan pembedahan tikus.Darah diambil melalui jantung dengan menggunakan spuitberukuran 3 cc. Darah yang telah diambil ditampung dalam blood tube dan disentrifugasi pada kecepatan 3000 rpm selama 10 menit.Plasma darah yang terletak pada bagian atas dipisahkan dan diambil untuk dianalisis konsentrasi MDA ${ }^{15}$.

\section{Pembuatan Kurva Baku}

Larutan stok pereaksi 1,1,3,3-tetraetoksipropana (TEP) konsentrasi $6 \mathrm{M}$ diencerkan menjadi 0,3; 0,4; 0,$5 ; 0,7 ; 0,8 ; 0,9$ ppm. Setiap konsentrasi TMP direaksikan dengan $1,0 \mathrm{~mL}$ TCA $20 \%$ dan $1,0 \mathrm{~mL}$ TBA $1 \%$ dalam pelarut asam asetat glasial $50 \%$. Semua larutan kemudian diinkubasi selama 45 menit pada suhu $95^{\circ} \mathrm{C}$.Setelah didinginkan, larutan disentrifugasi pada kecepatan $1000 \mathrm{rpm}$ selama 15 menit. Supernatan pada lapisan atas diukur absorbansinya dengan menggunakan spektrofotometer UV-Vis pada panjang gelombang $532,2 \mathrm{~nm}^{15}$.

\section{Pengukuran Sampel}

Pengukuran konsentrasi dari sampel percobaan dilakukan dengan cara yang sama seperti larutan standar, yaitu $1,0 \mathrm{~mL}$ plasma darah direaksikan dengan $1,0 \mathrm{~mL}$ TCA $20 \%$ dan $1,0 \mathrm{~mL}$ TBA $1 \%$ dalam asam asetat glasial 50\%, kemudian diinkubasi selama 45 menit pada suhu $95^{\circ} \mathrm{C}$, kemudian dibiarkan dingin. Larutan disentrifugasi selama 15 menit pada kecepatan 1000 rpm. Supernatan dipisahkan kemudian diukur absorbansinya menggunakan spektrofotometer UV-Vis pada panjang gelombang $532,2 \mathrm{~nm}$. Konsentrasi sampel diperoleh dengan memplot data absorbansi sampel ke dalam kurva standar ${ }^{15}$.

\section{Analisis Data}

Analisis statistik dilakukan dengan menggunakan program komputer Statistical Program Service Solution (SPSS) versi 17 trial.Analisis data menggunakan uji non parametric yaitu dengan Uji Uji Kruskal-Wallis dan dilanjutkan Uji MannWhitney.Uji statistik dilakukan pada derajat kepercayaan $95 \%$.

\section{HASIL DAN PEMBAHASAN}

\section{Determinasi Tanaman}

Determinasi tanaman dilakukan untuk memastikan identitas tanaman dan menghindari kesalahan dalam pengambilan tanaman.Hasil determinasi tanaman yang dilakukan di Laboratorium Biologi Fakultas Matematika dan Ilmu Pengetahuan Alam Universitas Tanjungpura Pontianak menunjukkan bahwa tanaman yang digunakan dalam penelitian ini adalah benar tanaman buas-buas (Premna cordifolia Linn) dari famili Verbenaceae spesies. 


\section{Ekstraksi}

Teknik ekstraksi daun buas-buas dalam penelitiaan ini menggunakan metode maserasi dengan pelarut etanol $70 \%$. Ekstrak etanol daun buasbuas yang diperoleh sebesar 88 gram dengan nilai rendemen $29,33 \%$.

\section{Penetapan Susut Pengeringan}

Hasil penetapan susut pengeringan ekstrak etanol daun buas-buas adalah 8,96 \%. Ekstrak dengan persentase $8,96 \%$ termasuk dalam rentang ekstrak kental yaitu $5-30 \%{ }^{16}$.

\section{Skrining Fitokimia}

Tabel 1. Hasil Skrining Fitokimia Ekstrak Etanol Daun Buas-Buas

\begin{tabular}{|c|c|}
\hline Pemeriksaan & Hasil \\
\hline Alkaloid & + \\
\hline Flavonoid & + \\
\hline Triterpenoid dan Steroid & + \\
\hline Tanin & - \\
\hline Fenol & + \\
\hline Saponin & + \\
\hline
\end{tabular}

Keterangan: $(+)$ positif : mengandung golongan senyawa; (-) negatif: tidak mengandung golongan senyawa.

Berdasarkan hasil yang diperoleh pada tabel 1, dapat dilihat bahwa pada ekstrak etanol $70 \%$ dari daun buas-buas mengandung senyawa yang tergolong alkaloid, flavonoid, triterpenoid, fenol, tanin dan saponin,

\section{Pengujian Antioksidan Perlakuan Hewan Uji}

Sumber radikal bebas yang digunakan adalah asap rokok yang berasal dari rokok tanpa filter. Hewan uji tikus dikondisikan sebagai perokok pasif yang terpapar asap rokok. Menurut Dewi et al (2003), asapasap yang dilepaskan ke udara lebih berbahaya karena kandungan nikotin yang lebih tinggi (4-6 kali) dibandingkan asap rokok yang dihisap oleh perokok ${ }^{17}$. Hewan uji diberi paparan asap rokok secara akut selama 14 hari dengan tiga batang rokok pada setiap kali pemaparan. Jumlah rokok yang digunakan didasarkan pada nilai $\mathrm{LD}_{50}$ nikotin untuk tikus yaitu sebesar $50 \mathrm{mg} / \mathrm{kg} \mathrm{BB}{ }^{18}$. Menurut Vanet all (2005), pemaparan rokok secara akut merupakan metode yang relatif mudah dan sensitif untuk menyelidiki efek spesifik dari asap rokok pada stress oksidatif. Paparan asap rokok secara akut dapat menyebabkan kerusakan jaringan yang diikuti dengan peningkatan produk peroksidasi lipid ${ }^{19 .}$ Sebelum diberikan perlakuan semua hewan uji diadaptasikan selama satu minggu untuk menghindari resiko timbulnya stres selama proses transportasi serta menyeragamkan pola makan ataupun pola hidup dengan lingkungan baru. Perlakuan ini bertujuan untuk meningkatkan berat badan tikus hingga sesuai dengan berat badan yang diinginkan pada pengujian.Berat badan yang digunakan pada saat pengujian berkisar antara 100200 gram. Berdasarkan hasil analisis statitistik data berat badan, hewan uji yang digunakan memiliki berat badan yang homogen $(\mathrm{p}>0,05)$. Hal ini menandakan hewan uji berada dalam kondisi lingkungan yang sama sehingga diharapkan tidak menimbulkan hasil yang bias pada hasil pengukuran kadar MDA.

Pengamatan yang dilakukan menunjukkan adanya perubahan pada hewan uji sebelum dan sesudah diberi paparan asap rokok. Perubahan yang terjadi menunjukkan terjadinya stres pada hewan uji.Perubahan yang terjadi meliputi dehidrasi yang ditandai dengan hewan uji yang berkeringat, keaktifan hewan uji yang menurun, detak jantung yang lebih cepat, bunyi seperti mengi pada saat bernapas dan meningkatnya suhu tubuh hewan.

\section{Pengambilan Sampel Darah}

Pengorbanan atau terminasi hewan uji dilakukan pada hari kelima belas dari tiap kelompok perlakuan.Sebelum diterminasi hewan uji dipuasakan selama satu malam. Hewan uji diterminasi secara dislocatio servicalis yaitu dislokasi tulang leher hewan uji. Setelah itu, hewan uji dibedah dan diambil darahnya melalui organ jantung. Menurut Mitruka dan Rawnsley (1981), volume darah maksimal dapat diambil dari jantung dibandingkan volume darah yang diambil dari vena ekor ${ }^{20}$.

Darah yang diperoleh ditempatkan dalam blood tube berisi EDTA yang berfungsi sebagai antikoagulan, kemudian disentrifugasi untuk memisahkan bagian supernatan dan platelet.Bagian yang diambil adalah supernatan yang mengandung plasma darah.Pengukuran MDA pada plasma darah karena sebagian besar MDA pada darah terdapat di dalam plasma, selain pada serum dan jaringan ${ }^{21}$. Plasma darah yang diperoleh selanjutnya digunakan untuk pemeriksaan kadar MDA.

\section{Metode Pengukuran Kadar MDA}

Metode pengukuran MDA yang digunakan adalah metode TBA (Thiobarbituric Acid). Menurut Yagi (1994), metode TBA mempunyai nilai kepekaan yang tinggi terhadap radikal bebas dan mudah diaplikasikan untuk sampel dalam berbagai tahap 
oksidasi. TBA akan bereaksi dengan gugus karboksilat dari MDA melalui penambahan nukleofilik membentuk kompleks MDA-TBA dalam suasana asam dan menghasilkan produk yang berwarna sehingga dapat dikuantifikasi dengan spektrofotometri ${ }^{22}$.

Plasma yang diperoleh kemudian ditambahkan TCA $20 \%$ (Trichloroacetat) dan TBA 1\%.Penambahan TBA harus dalam keadaan asam yaitu dengan ditambahkan asam asetat glasial 50\%, agar dapat berekasi sempurna dengan MDA.Sedangkan TCA berfungsi untuk mengendapkan protein yang terdapat di dalam plasma.Selanjutnya dilakukan inkubasi slama 45 menit pada suhu $95^{\circ} \mathrm{C}$ untuk mempercepat reaksi ${ }^{22}$.Kemudian disentrifugasi untuk memisahkan supernatan berwarna merah jambu-kecokelatan. Supernatant yang diperoleh kemudian diukur kadarnya menggunakan spektrofotometri UV-Vis. Pengukuran kadar MDA dilakukan melalui pengukuran absorbansi plasma darah dari tiap kelompok percobaan.

\section{Pembuatan Kurva Baku}

Persamaan kurva baku diperoleh setelah membuat kurva baku kalibrasi TMP dengan menggunakan larutan standar yaitu 1,1,3,3tetrametoksipropan. TMP merupakan prekusor dari MDA, karena sifatnya yang tidak stabil sehingga dijadikan sebagai standar MDA. TMP akan dihidrolisis oleh air menjadi MDA dan alkohol.

Panjang gelombang MDA yang diperoleh dari pembuatan kurva baku adalah 532,2 nm. Panjang gelombang MDA teoritis adalah $532 \mathrm{~nm}^{22}$. Toleransi panjang gelombang yang diperbolehkan untuk jangkauan $400 \mathrm{~nm}$ hingga $600 \mathrm{~nm}$ yaitu lebih kurang $3 \mathrm{~nm}$, sehingga panjang gelombang yang diperoleh dapat digunakan untuk mengukur kadar MDA sampel

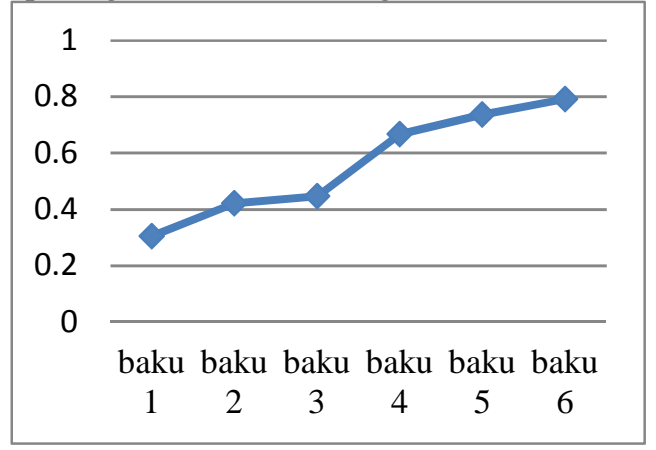

Gambar 1. Kurva Regresi Linier MDA
82. Persamaan kurva baku yang diperoleh adalah $\mathrm{y}=0,8264285714 \quad \mathrm{x} \quad 0,06580952381$ dengan $\mathrm{r}=0,993066$.

\section{Analisis Kadar MDA}

Kadar MDA plasma dianalisis secara statistik menggunakan uji Kruskal-Wallis dan uji MannWhitney. Uji Kruskal-Wallis digunakan untuk melihat perbedaan kadar MDA plasma antara kelompok normal, kelompok kontrol positif, kelompok kontrol negatif, kelompok ekstrak etanol daun buas-buas dengan dosis 200, 400 dan 600 $\mathrm{mg} / \mathrm{kg}$ BB. Berdasarkan hasil analisis bahwa paling sedikit ada dua kelompok perlakuan yang memiliki kadar MDA plasma yang berbeda signifikan $(\mathrm{p}<0,05)$.

Tabel 2.Perbandingan Kadar MDA Plasma Kelompok Perlakuan dengan Uji Kruskal-Wallis

\begin{tabular}{|c|c|c|}
\hline Kelompok & $\begin{array}{c}\mathrm{N}=4 \\
\text { mean } \pm \mathrm{SD} \\
\mathrm{MDA}(\mathrm{ppm})\end{array}$ & \multirow{2}{*}{$p$-value } \\
\hline Normal & $0,094 \pm 0,080$ & \\
\hline Vitamin E & $0,051 \pm 0,045$ & \multirow{2}{*}{0,003} \\
\hline Negatif & $13,743 \pm 2,839$ & \\
\hline Dosis 1 & $9,142 \pm 2,365$ & \\
\hline Dosis 2 & $0,120 \pm 0,019$ & \\
\hline Dosis 3 & $0,053 \pm 0,041$ & \\
\hline
\end{tabular}

Keterangan: $p$-value $<0,05$ = berbeda signifikan Kemudian dilanjutkan analisis untuk mengetahui perbedaan kadar MDA

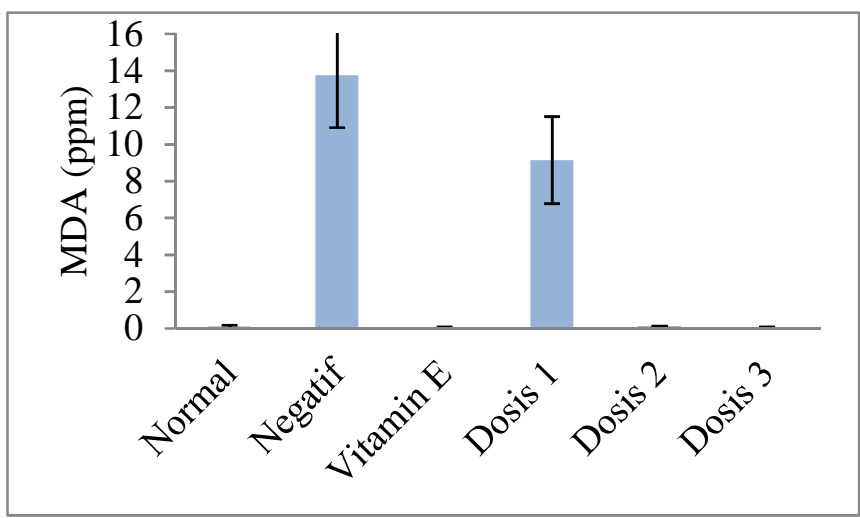

Gambar 2. Kurva Kadar MDA Plasma Tikus Wistar Jantan Pasca Paparan Asap Rokok 
plasma antar kelompok perlakuan menggunakan uji Mann-Whitney.

Berdasarkan hasil analisis kadar MDA plasma kelompok perlakuan negatif memiliki perbedaan yang signifikan terhadap semua kelompok $(\mathrm{p}<0,05)$. Kelompok negatif merupakan kelompok yang hanya diberi paparan asap rokok tanpa diberikan asupan antioksidan. Radikal bebas dari asap rokok menyebabkan terjadinya peroksidase asam lemak tak jenuh membran sel yang memperkuat stres oksidatif $^{23}$.Menurut Somwanshi et all(2013) bahwa terjadi peningkatan kadar MDA akibat adanya paparan asap rokok ${ }^{24}$.

Penurunan kadar MDA plasma secara signifikan terjadi pada kelompok perlakuan positif. Kadar MDA plasma kelompok kontrol positif berbeda signifikan terhadap kelompok dosis 1 dan dosis $2(\mathrm{p}<0,05)$, tetapi tidak berbeda signifikan terhadap kelompok normal dan dosis 3 ( $>>0,05)$. Menurut Traber et al (2007), vitamin E merupakan penangkap radikal peroksil yang dapat mencegah propagasi radikal bebas pada membran sel dan plasma lipoprotein ${ }^{25}$. Berdasarkan O'Donnel (1997) radikal peroksil akan berikatan dengan atom $\mathrm{H}$ fenolik dari gugus $\mathrm{OH}$ tokoferol. Tokoferol menangkap radikal peroksil lebih cepat daripada radikal peroksil yang akan bereaksi dengan substrat lipid. Tokoferol akan menjadi radikal bebas yang stabil (tocopheroxyl radical). Reaksi antara tocopheroxyl radical dan radikal peroksil akan menghasilkan dua produk yang bersifat stabil yaitu $\alpha$-tocopherylquinone dan epoxyquinone ${ }^{26}$.

Kadar MDA plasma kelompok dosis 3 lebih rendah secara signifikan jika dibandingkan dengan kelompok dosis 1 dan dosis 2. Selain itu memiliki kadar MDA yang tidak bebrbeda signifikan terhadap kelompok normal dan kelompok vitamin E Sehingga dapat disimpulkan dosis ekstrak etanol daun buasbuas yang dapat menurunkan kadar MDA secara signifikan adalah $600 \mathrm{mg} / \mathrm{kg}$ BB. Kemampuan dalam menurunkan kadar MDA karena diduga kandungan flavonoid dari ekstrak etanol daun buas-buas. Selain itu kandungan senyawa lain seperti alkaloid, triterpen dan saponin diduga ikut berperan sebagai antioksidan.

Menurut Wayanet al (2012) flavonoid adalah antioksidan eksogen yang telah dibuktikan bermanfaat dalam mencegah kerusakan sel akibat stres oksidatif, terdapat dua mekanisme flavonoid sebagai antioksidan yaitu mendonorkan ion hidrogen sehingga menetralisir efek toksik dari radikal bebas serta meningkatkan ekspresi gen antioksidan endogen melalui aktivasi nuclear factor erythroid 2 related factor 2 (Nrf2) sehingga terjadi peningkatan gen yang berperan dalam sistesis enzim antioksidan endogen 27. Kekuatan aktivitas antioksidan dari flavonoid bergantung pada jumlah dan posisi dari gugus $-\mathrm{OH}$ yang terdapat pada molekul.Kekuatan aktivitas antioksidan dari flavonoid bergantung pada jumlah dan posisi dari gugus - $\mathrm{OH}$ yang terdapat pada molekul.Semakin banyak gugus -OH pada flavonoid, maka aktivitas antiradikalnya semakin tinggi ${ }^{28}$.

Berdasarkan Nzaramba (2008) kompenen fenolik merupakan terminator dari radikal bebas dan sebagai pengkelat ion logam redoks aktif. Ion logam ini memungkinkan peranannya untuk mengatalisis reaksi peroksidasi lipid. Antioksidan fenolik ini menghalangi oksidasi lipid dan molekul lain dengan cara mendonasikan atom hidrogen ke senyawa radikal membentuk intermediet radikal fenoksil. Senyawa intermediet radikal fenoksil relatif stabil sehingga tidak mampu lagi menginisiasi reaksi radikal selanjutnya .Aktivitas biologis yang tinggi pada senyawa fenolik ini terletak pada posisi dan jumlah gugus hidroksil $(-\mathrm{OH})^{29}$.

Menurut Dinara et al (2007), senyawa alkaloid dapat bertindak sebagai penangkap radikal bebas dan dapat mencegah terjadinya peroksidasi lipid pada hepatik mikrosomal ${ }^{30}$. Senyawa alkaloid, terutama indol, memiliki kemampuan untuk menghentikan reaksi rantai radikal bebas secara efisien.Senyawa radikal turunan dari senyawa amina ini memiliki tahap terminasi yang sangat lama. Senyawa alkaloid lain yang bersifat antioksidan adalah kafein yang dapat bertindak sebagai peredam radikal hidroksil. Namun dalam penelitian ini belum dapat diketahui jenis alkaloid yang berperan dalam bioaktivitas antioksidan ${ }^{31}$.

Berdasarkan Lichuan et al (2009), triterpenoid secara potensial dapat menginduksi pengekspresian gen Nrf2 dan mengaktifkan mengaktifkan pathway ARE (Antioxidant Response Element) dalam sel neuronal. Nrf2/ARE akan meregulasi lebih dari 200 gen termasuk gen antioksidatif ${ }^{32}$. Selain itu menurut Grassman (2005), triterpenoid akan mengikat radikal HOO* yang dapat bereaksi secara cepat dengan radikal lonoleilperoksil sehingga membawa reaksi menuju tahap terminasi ${ }^{33}$. Senyawa saponin dapat bertindak sebagai antioksidan dan memiliki kemampuan dalam menangkap radikal bebas. Kemampuan senyawa saponin dalam menurunkan stress oksidatif pada tikus yang diinduksi aloksan sudah dilaporkan oleh Alii et al (2014) ${ }^{34}$.

\section{KESIMPULAN}

Kesimpulan yang dapat diambil berdasarkan hasil penelitian ini adalah:

1. Ekstrak etanol daun buas-buas dapat menurunkan kadar MDA plasma tikus yang terpapar asap rokok.

2. Dosis ekstrak $600 \mathrm{mg} / \mathrm{kg}$ BB dapat menurunkan kadar MDA plasma secara signifikan. 


\section{DAFTAR PUSTAKA}

1. Yanbaeva DG, Dentener MA, Creutzberg EC, Wesseling G, Wouters EF. Systemic Effect of Smoking. Chest. Mei 2007. 131(5): 1557-1566.

2. World Health Organization. WHO Report: the global tobacco epidemic. Indonesia: World Health Organization; 2013.

3. Kementerian Kesehatan Republik Indonesia. Riset Kesehatan Dasar 2013. Jakarta: Badan Penelitian dan Pengembangan Kesehatan Kementerian Kesehatan Republik Indonesia; 2013.

4. Nagamma T, Anjaneyulu K, Baxi J, Dayaram PP. Effects of Cigarette Smoking on Lipid Peroxidation and Antioxidant Status in Cancer Patients from Western Nepal. Asian Pacific J Cancer Prev. 2007. 13(1): 313-316.

5. Sela S, Shurtz-Swirski R, Awad J, Shapiro G, Nasser L, Shasha, S. M. The Involvement of Peripheral Polymorphonuclear Leukocytes in the Oxidative Stress and Inflammation among Cigarette Smokers. Israel Medical Association Journal. Nopember 2004. 4(11): 1015-1019.

6. Rumley AG, Woodward M, Rumley A. Plasma Lipid Peroxides: Relationships to Cardiovascular Risk Factors and Prevalent Cardiovascular Disease. QJM. Agustus 2004. 97(12): 809-816.

7. Yueniwati Y, Ali M. Pengaruh Paparan Asap Rokok Kretek terhadap Peroksidasi Lemak dan System Proteksi Superoksid Dismutase Hepar Tikus Wistar. Jurnal Kedokteran Yarsi. 2004. 12(1): 85-92.

8. Wulansari D, Chairul. Penapisan Aktivitas Antioksidan dan Beberapa Tumbuhan Obat Indonesia Menggunakan Radikal 2,2-Diphenyl-1 Picrylhydrazyl (DPPH). Majalah Obat Tradisional.2011.16(1): 22-25

9. Ali Mat MS. Analysis of Phenolics and Other Phytochemicals in Selected Malaysian Traditional Vegetables and Their Activities In Vitro. Thesis. 2008. Universtas of Glasgow.

10. Bakar FA, Mohamed S, Hamid AA, Mustafa RA. Total Phenolic Compounds, Flavonoids and Radical Scavenging Activity of 21 Selected
Tropical Plants. Journal Of Food Science. Januari- Februari 2010. 75(1): 28-35.

11. Departemen Kesehatan Republik Indonesia. Parameter Standar Umum Ekstrak Tumbuhan Obat. Jakarta: Departemen Kesehatan Republik Indonesia; 2000. p. 5, 9-12.

12. Raaman, N. Phytochemical Technique. New Delhi: New India Publishing Agency; 2006. Hal 21-22, 230 .

13. Robinson, T. The Organic Constituents of Higher Plants Their Chemistry and Interrelationships. 5th Ed. North Amherst: Cordus Press; 1983.

14. Kristanti AN, Aminah NS, Tanjung M, Kurniadi B. Buku Ajar Fitokimia. Surabaya: Airlangga University Press. 2008. Hal 48-49.

15. Momuat LI, Meiske SS, Ni Putu Purwati. Pengaruh VCO Mengandung Ekstrak Wortel terhadap Peroksida Lipid Plasma. Jurnal Ilmiah Sains. Oktober 2013. 11(2): 296-301.

16. Voigt R. Buku Pelajaran Teknologi Farmasi. Yogyakarta : Gadjah Mada University Press; 1995. Hal. 561.

17. Dewi S, Budi H, Hendra F. Penentuan Kadar Nikotin Dalam Asap Rokok. Makara Kesehatan. Desember 2013. 7(2): 38-41.

18. Bradbury, S. Reregistration Eligibility Decision for Nicotine. DirectorSpecial Review andReregistration Division. United States Prevention; 2008.

19. Van der Vaart, DS Postma, W Timens, NHT Ten Hacken. Accute Effect of Cigarette Smoke on Inflammation and Oxidative Stress: a Review. Thorax. 2004. 59: 713-721.

20. Mitruka BM, Rawnsley HM. Clinical, Biochemical and Hematological Reference Values in Normal Experimental Animals and Normal Humans. New York: Masson Publishing; 1981. Hal 413.

21. Konig D, Berg A. Exercise and Oxidative Stress: Is there a Need for Additional Antioxidant. Osterreichisches J Fur Sportmedizin. 2002. 3: 615. 
22. Yagi K. Free Radical in Diagnostic Medicine. Armstrong D, editor. New York: Plenum Pr; 1994.

23. Kevin C, Kregel, Hannah J, Zhang. An Integrated View of Oxidative Stress in Aging: Basic Mechanisms, Functional Efects, and Pathological Considerations. Am J Physiol Regul Integr Comp Physiol. Agustus 2006. 292(1): 18-36.

24. Somwanshi DS, Mahesh BM, Sandeep G, Mahendra B, Sachin BI. Effect of Cigarette Smoking on Lipid Peroxidation In Semen. International Journal of Basic and Applied Medical Sciences. Mei- Agustus 2013. ISSN: 2277-2103. 3(2): 289-294.

25. MG Traber, J Atkinson. Vitamin E, Antioxidant and Nothing More. Free Radical biology and Medicine. Juli 2007. 43(1): 4-15.

26. O'Donnel, VB Chumley, PH Hogg,Bloodsworth A, Darley-Usmar VM, Freeman BA. Nitric Oxide Inhibition of Lipid Peroxidation: Kinetics of Reactions with Lipid Peroxyl Radicals and Comparison with Tocopherol. Biochem. 1997. 15216-15223.

27. I Wayan S, I Made J. Ekstrak Air Daun Ubi Jalar Ungu Memperbaiki Profil Lipid dan Meningkatkan Kadar SOD Darah Tikus yang Diberi Makanan Tinggi Kolesterol. Medicina. Mei 2012. 43(2): 67-70.

28. Amic D, Beslo D, Trinajstic N, Davidovic. Structure-Radical Scavenging Activity Relationships of Flavonoids. Croatia Chem Acta. Oktober 2002. ISSN-0011-16437. 6(1): 55-61.

29. Nzaramba MN. Relationships Among Antioxidants, Phenolics, and Specific Gravity in Potato Cultivars, and Evaluation of Wild Potato Species for Antioxidants, Glycoalkaloids, and Anti-Cancer Activity on Human Prostate and Colon Cancer Cells In Vitro. Disertasi. 2008. Texas A\&M University.

30. Yuhernita dan Juniarti. Analisis Senyawa Metabolit Sekunder dari Ekstrak Metanol Daun Surian Yang Berpotensi Sebagai Antioksidan. MAKARA. April 2011. 15(1): 48-52.

31. Dinara JM, Marc FR, Jane MB, Joa o APAH, Jenifer S. Antioxidant Properties of B-Carboline Alkaloids are Related to Their Antimutagenic and Antigenotoxic Activities. Mutagenesis. Juni 2007. 22(4): 293-302.

32. Lichuan Yang, Noel Y. Calingasan, Bobby Thomas, Rajnish KC, Mahmoud Kiaei, Elizabeth JW, Karen TL, Charlotte Williams, Darlene Royce, Renee Risingsong, Eric SM, Jason D. Morrow3, Michael Sporn, M. Flint Beal. Neuroprotective Effects of the Triterpenoid, CDDO Methyl Amide, a Potent Inducer of Nrf2Mediated Transcription. Plos One. Juni 2009. 6: 1-13.

33. Grassman J. Terpenoids as Plant Antioxidant. Germany: Elseiver Inc; 2005. Hal 516.

34. Alli Smith YR, Adanlawo IG. In Vitro and In Vivo Antioxidant Activity of Saponin Extracted from The Root ff Garcinia Kola (Bitter Kola) on Alloxan-Induced Diabetic Rats. World Journal of Pharmacy and Pharmaceutical Sciences. Juni 2014. 3(7): 8-26, ISSN 2278 - 4357. 